PAEDAGOGIA CHRISTIANA

2/26(2010) - ISSN 1505-6872

Jerzy Kostorz ${ }^{*}$

Opole

\title{
Wychowanie do postawy ekumenizmu w nauczaniu religii - doświadczenia katolickie
}

Wychowanie jest procesem, który wprost wiąże się z kształtowaniem różnych postaw dzieci i młodzieży. Obejmuje bowiem różne płaszczyzny rozwoju osoby i różne dziedziny ludzkiego działania, ukierunkowane na wszechstronny rozwój uczniów. Jedną z nich stanowi realizowane w ramach szkolnych lekcji religii wychowanie dzieci i młodzieży do postawy ekumenizmu. W związku z tym, celem prezentowanego tekstu jest ukazanie tej problematyki na kanwie doświadczeń katolickich. Nie chodzi tu jednak o odwołanie do badań empirycznych, lecz jedynie do opisanych w dokumentach Kościoła katolickiego i w literaturze teologiczno-katechetycznej założeń wychowania do postawy ekumenizmu. Sama problematyka tego wychowania $\mathrm{w}$ dzisiejszym świecie nacechowanym pluralizmem religijnym wydaje się być warta popularyzacji. To jednak wymaga odczytania na nowo wskazań opisanych w podstawowych dokumentach ekumenicznych i katechetycznych Kościoła, które stanowią podstawę i wytyczają charakterystyczne linie rozwojowe dla katechezy i innych działań duszpasterskich posiadających ekumeniczny wymiar. Zatem na początku artykułu wyjaśnię podstawowe pojecie, jakim jest „postawa ekumeniczna”. Następnie opiszę założenia wychowania w duchu ekumenicznym według dokumentów Kościoła katolickiego. Zwrócę też uwagę na wynikające z tych założeń implikacje dla teorii i praktyki nauczania religii. W zakończeniu dokonam syntetycznego zestawienia prezentowanej problematyki i wskażę na potrzebę

* Ks. dr hab. Jerzy Kostorz - wykładowca katechetyki, pracuje na Wydziale Teologicznym Uniwersytetu Opolskiego, duszpasterz akademicki. 
pogłębionej refleksji teoretycznej i odnowę ekumenicznie ukierunkowanego nauczania religii.

\section{Pojęcie „postawa ekumeniczna"}

„Postawa ekumeniczna” to pojęcie, które zawiera w sobie dwa słowa określające jej zakres znaczeniowy. Pierwsze, wywodzące się od greckiego wyrazu oikoumene, oznaczającego świat zamieszkały przez ludzi, wskazuje na ruch na rzecz jedności chrześcijan. Określa konkretny wymiar życia duchowego, intelektualnego, duszpasterskiego i liturgicznego całego Kościo$\mathrm{ra}^{1}$. Pozwala wyodrębnić ekumenizm duchowy, naukowy i praktyczny ${ }^{2}$. Jednak współcześnie, mówiąc o ekumenizmie, teolodzy zwracają uwagę na dwa jego znaczenia: węższe i szersze. Pierwsze znaczenie określa poglądy i postawy wyrażające dążenie do zjednoczenia chrześcijan wszystkich wyznań w jednym Kościele Chrystusowym przy zachowaniu pluralizmu teologicznego i wyznaniowego ${ }^{3}$. Chodzi tu o „całość wysiłków i działań zmierzających do przywrócenia jedności wśród chrześcijan" ". Drugie natomiast znaczenie ekumenizmu ma charakter szerszego ujęcia. Określa duchową postawę więzi i jedności, poczucia braterstwa wszystkich wierzących bez względu na różnice związane z religią, pochodzeniem czy narodowością ${ }^{5}$. W tym kontekście szczególnego znaczenia nabiera samo pojęcie „postawa”. Zwykle określa ono „ukształtowaną w procesie zaspokajania potrzeb, w określonych warunkach społecznych, względnie zgodną i stałą organizację wiedzy, przekonań, uczuć i motywów oraz pewnych form działania i reakcji ekspresywnych podmiotu, związaną z określonym przedmiotem lub klasą przedmiotów"6. Tak więc postawa jest nabytym, a nie wrodzonym, elementem osobowości człowieka. Ukonkretnia się ona w pewnym zespole cech określających ustosunkowanie człowieka wobec przedmiotu postawy. Jako taka obejmuje trzy elementy: składnik poznawczy (wiedza, przekonania i nastawienia), s. 33-34.

1 J. Budniak, Ekumenizm jutra na przykładzie Ślaska Cieszyńskiego, Katowice 2002,

2 Zob. więcej na ten temat u: K. Sosna, Miejsce ekumenizmu w katechezie, w: J. Budniak (red.), Ekumenizm w duszpasterstwie parafialnym, Katowice 2007, s. 51-55.

3 W. Hanc, Ekumenizm, w: R. Łukaszyk, L. Bieńkowski, F. Gryglewicz (red.), Encyklopedia katolicka, t. 4, Lublin 1983, k. 853.

${ }^{4}$ T. Vetrali, Ze św. Franciszkiem z Asyżu w duchu dialogu ekumenicznego, w: Ewangelizacja. Ekumenizm. Charyzmat Franciszkański, Warszawa 1994, s. 25.

5 W. Hanc, Ekumenizm, k. 853.

6 T. Mądrzycki, Psychologiczne prawidlowości ksztaltowania siępostaw, Warszawa 1971, s. 21. 
emocjonalny (uczucia) i behawioralny (działanie). W postawie ekumenicznej przedmiotem jest jedność ducha, doktryny i działalności praktycznej na płaszczyźnie religijnej z ludźmi z innego wyznania czy religii ${ }^{7}$.

W świetle powyższych stwierdzeń najogólniej przez postawę ekumeniczną rozumiemy względnie stałą organizację wiedzy, przekonań, uczuć i motywów oraz pewnych form działania i reakcji ekspresywnych podmiotu, związaną z ekumenizmem w znaczeniu węższym i szerszym. Jej ukonkretnienie dokonuje się w gruntownym poznaniu doktryny własnego Kościoła, w poznaniu inaczej wierzących, w otwartości na wyznawców innych religii oraz $\mathrm{w}$ dążeniu do jedności z braćmi odłączonymi ${ }^{8}$. Stąd też uzasadnione wydaje się mówienie o wychowaniu do postawy ekumenizmu i rozpatrywanie tej problematyki w odniesieniu do nauczania religii. Postawa ta w najogólniejszym ujęciu oznacza trwałe nastawienie wobec kogoś lub czegoś, przechodzące bezpośrednio $\mathrm{w}$ zachowanie ${ }^{9}$, przy czym jej przedmiotem w odniesieniu do ekumenizmu jest

wszystko, co może przyczynić się do jedności chrześcijan w wierze, Kościele, w chrześcijańskim życiu i odpowiedzialnym działaniu wobec świata: a więc wzajemna informacja o życiu i doktrynie; wzajemne lepsze zrozumienie teologii każdego Kościoła; próba przełożenia własnej teologii na język innej teologii, i na odwrót; próba przezwyciężenia prawdziwych różnic doktrynalnych; organizowanie wspólnego działania ${ }^{10}$.

W myśl tych założeń powinno wpisywać się ekumenicznie ukierunkowane nauczanie religii. Do jego istotnych zadań należy bowiem rozwijanie postawy ekumenizmu ${ }^{11}$.

7 Więcej o tym pisze m.in. J. Królikowski, Formacja postawy ekumenicznej, w: J. Budniak (red.), Ekumenizm w duszpasterstwie, s. 25-34.

${ }^{8}$ Tamże.

9 A. S. Reber, Stownik psychologii, Warszawa 2002, s. 526.

10 K. Rahner, H. Vorgrimler, Mały stownik teologiczny, Warszawa 1996, k. 397-400.

$11 \mathrm{Na}$ temat formacji ekumenicznej piszą między innymi Z. Glaeser, Ku petni jedności w Chrystusowym Kościele, w: K. Konecki, Z. Pawlak, K. Rulka (red.), Ekumenizm. Teologia. Kultura, Włocławek 2006, s. 77-80; tenże, Ku eklezjologii „,Kościołów siostrzanych”. Studium ekumeniczne, Opole 2000, s. 235-237; W. Hładowski, Wychowanie do ekumenizmu, w: W. Hryniewicz, J. S. Gajek, S. J. Koza (red.), Ku chrześcijaństwu jutra, Lublin 1996, s. 723-730. 


\section{Założenia wychowania do postawy ekumenizmu według dokumentów Kościoła katolickiego i ich implikacje w nauczaniu religii}

Wychowanie do postawy ekumenizmu opiera się na silnych przesłankach i założeniach teologicznych. Zostały one opisane w dokumentach Kościoła katolickiego, a ukonkretnione $\mathrm{w}$ programach nauczania religii. Już Ojcowie II Soboru Watykańskiego w dekrecie o ekumenizmie Unitatis redintegratio $^{12}$ zwrócili uwagę na elementy istotne nie tylko dla wychowania w duchu ekumenicznym. Pierwsze słowa dekretu wskazują jednoznacznie na kierunek myśli ekumenicznej Vaticanum II, według której ekumenizm nie polega tylko na rozwijaniu międzywyznaniowej przyjaźni, ale jego zamierzeniem jest troska o faktyczne „przywrócenie jedności”. Autorzy dekretu dostrzegli w dialogu ekumenicznym swoistego rodzaju znak czasu i dzieło Ducha Świętego ${ }^{13}$. Określili też ruch ekumeniczny jako

działania i przedsięwzięcia podejmowane i stosowane do różnych potrzeb Kościoła i warunków chwili, ustanawiane w celu wspierania jedności chrześcijan, jak na przykład wszelkie wysiłki zmierzające do usunięcia słów, opinii i czynów, które w świetle sprawiedliwości i prawdy nie odpowiadałyby sytuacji odłączonych braci i z tej przyczyny utrudniały wzajemne stosunki z nimi; następnie «dialog» podjęty między biegłymi i odpowiednio wykształconymi ekspertami, prowadzony na zorganizowanych $\mathrm{w}$ duchu religijnym spotkaniach chrześcijan z różnych Kościołów lub Wspólnot; podczas owego dialogu każdy wyjaśnia głębiej naukę swej Wspólnoty i przejrzyście przedstawia jej szczególne znamiona (DE 4).

Według Dekretu, dążenie do jedności realizowane przez współczesny ruch ekumeniczny wymaga respektowania zasady wzajemnego szacunku i różnorodności. Wyraża ona prawdę, iż Kościół, zachęcając do poznania i ukochania braci odłączonych, do dawania im przykładu chrześcijańskiego życia, do dialogu, nie wyklucza różnorodności form życia duchowego, karności kościelnej, obrzędów liturgicznych czy nawet teologicznego opracowania prawd objawionych. Owa różnorodność Kościoła jest nie tylko doskonałym przejawem jego katolickości czy powszechności, ale również wskazuje

${ }^{12}$ Sobór Watykański II, Dekret o ekumenizmie Unitatis redintegratio, Watykan 1964 (odtąd skrót DE).

${ }_{13}$ P. Jaskóła, Zagadnienia ekumeniczne, Opole 2004, s. 38; zob. także: W. Dudek, Teologia w świetle Dekretu , Unitatis redintegratio”, „Ateneum Kapłańskie” 61 (1969), z. 1, s. 54-69. 
na jego apostolskość ${ }^{14}$. Drugi rozdział Dekretu o ekumenizmie wydaje się być jeszcze bliższy nauczaniu religii, gdyż zawiera praktyczne wskazania dotyczące urzeczywistnienia ekumenizmu w życiu i działalności duszpasterskiej Kościoła. Preludium do tego rozdziału, zatytułowanego: Realizowanie ekumenizmu, stanowią słowa podkreślające prawdę, iż ekumenizm dotyczy całego Kościoła, zarówno wiernych, jak i pasterzy ${ }^{15}$, tak w codziennym życiu, jak i w uprawianiu teologii (DE 5). Dlatego Sobór w tym dokumencie zachęca, aby wierni Kościoła katolickiego, rozpoznając znaki czasu, pilnie uczestniczyli w dziele ekumenicznym (por. DE 4). Ekumenizm jest bowiem konkretnym wymiarem życia duchowego, intelektualnego, duszpasterskiego i liturgicznego całego Kościoła ${ }^{16}$. Pierwszym krokiem w kierunku jedności jest permanentna odnowa Kościoła, gdyż potrzebuje on stałej reformy, powrotu do swej pierwotnej czystości i wysiłku w celu zachowania bezwzględnej wierności Chrystusowi i Jego nauce. Dotyczy to również innych Wspólnot, ponieważ - zdaniem Soboru - powrót do pierwotnej czystości życia ewangelicznego jest drogą do pojednania i zjednoczenia (por. DE 6) ${ }^{17}$. Drugim natomiast środkiem służącym jedności jest wewnętrzna przemiana chrześcijan ${ }^{18}$, a więc to, co wprost wiąże się z integralnym wychowaniem. Słusznie Ojcowie Soboru stwierdzają, że „rzeczywisty ekumenizm nie istnieje bez wewnętrznej przemiany. Wszak z nowości ducha, z zaparcia się samego siebie i z swobodnego wylania miłości pochodzą i dojrzewają pragnienia jedności. Dlatego u Ducha Świętego musimy wypraszać łaskę szczerego umartwienia, pokory i cichości w posłudze, a także wspaniałomyślności ducha wobec drugich" (DE 7). W tej części Dekretu pojawia się ważne dla wychowania określenie ,ekumenizm duchowy”, na który składają się nawrócenie serca, świętość życia i modlitwa ${ }^{19}$. Według dokumentu, ekumenizm duchowy stanowi

14 W. Miziołek, Wprowadzenie do zagadnień ekumenicznych, Warszawa 1986, s. 33; por. P. Jaskóła, Zagadnienia, s. 40-41.

15 Por. J. Pytel, Ekumeniczna postawa duszpasterza, „Ateneum Kapłańskie” 61 (1969), z. 1, s. 85-91; T. Lenkiewicz, Ekumenizm w plaszczyźnie duszpasterskiej, „Ateneum Kapłańskie” 61 (1969), z. 1, s. 70-84.

16 J. Budniak, Ekumenizm jutra, s. 33-34.

17 Por. A. A. Napiórkowski, Zagadnienia ekumeniczne, Kraków 2001, s. 84; A. Zuberbier, Różne formy ekumenizmu prowadzace do petnej jedności, „A teneum Kapłańskie” 61 (1969), z. 1, s. 39-46; W. Hanc, Pojęcie ekumenizmu w świetle dekretu ,Unitatis redintegratio” II Soboru Watykańskiego, w: Rada Naukowa Konferencji Episkopatu Polski, Kościół w życiu publicznym. Teologia polska i europejska wobec nowych wyzwań, Lublin 2004, s. 408-409.

18 Por. L. Orzeł, Podstawowa zasada ekumenizmu: ku petni Kościoła przez odnowe wewnętrzna, „Ateneum Kapłańskie” 61 (1969), z. 1, s. 29-38.

19 Zob. Z. Glaeser, Ku eklezjologii, s. 224-232. 
„duszę całego ruchu ekumenicznego" (DE 8) ${ }^{20}$. Dekret gorąco zachęca do wspólnej modlitwy z braćmi odłączonymi, przy okazji choćby styczniowego Tygodnia Modlitw o Jedność Chrześcijan, bądź też w innych specjalnych okolicznościach. Modlitwa ta winna dokonywać się zawsze w duchu słów Jezusa w Wieczerniku, kiedy prosił o jedność wszystkich swoich uczniów ${ }^{21}$. W dalszej części dekret porusza kolejne, ważne dla wychowania do postawy ekumenicznej kwestie. Dotyczą one wzajemnego poznania i dialogu teologicznego (DE 9-11). W myśl autorów dokumentu ważne jest to, aby informacja o innych wyznaniach chrześcijańskich była zawsze uczciwa, zgodna z prawdą i duchem życzliwości. Równocześnie należy jasno i nieskazitelnie demonstrować całą naukę Kościoła, gdyż fałszywy irenizm, polegający na „zaciemnianiu” prawdy i ukrywaniu różnic, z pewnością nie służy właściwemu ekumenizmowi. Dialog ekumeniczny powinien przebiegać w atmosferze umiłowania prawdy i w nastawieniu pełnym miłości i pokory (DE 11$)^{22}$. Tu pojawia się bardzo istotna, zarówno dla samego dialogu ekumenicznego, jak i dla nauczania religii, kwestia „hierarchii prawd”.

Porównując doktryny, niech pamiętają [teologowie katoliccy] o istnieniu porządku czy «hierarchii» prawd nauki katolickiej, ponieważ różny jest ich związek z fundamentami wiary chrześcijańskiej. W ten sposób utorowana zostanie droga, która dzięki braterskiemu współzawodnictwu pobudzi wszystkich do głębszego poznania i jaśniejszego ukazania niezgłębionych bogactw Chrystusowych (DE 11) $)^{23}$.

Na końcu tego rozdziału Ojcowie Soboru jako skuteczny środek w wysiłkach ekumenicznych wymieniają współpracę chrześcijan w dziedzinie społecznej. Dotyczy to takich spraw, jak: pokój na świecie, pomoc krajom rozwijającym się, zwalczanie głodu i analfabetyzmu, nędzy, dążenie do sprawiedliwości społecznej i do układania stosunków społecznych w du-

20 P. Jaskóła, Zagadnienia, s. 42; zob. S. Nagy, Kościół na drogach jedności, Wrocław 1985, s. 227-275; S. Szymański, Ekumenizm duchowy - duszq ekumenizmu, „Ateneum Kapłańskie” 61 (1969), z. 1, s. 47-53; W. Hanc, Ekumeniczny wymiar teologii w zakresie chrześcijańskiej duchowości, „Studia Oecumenica” 1 (2001), s. 75-90; Z. Tonkiel, Zagadnienia wybrane z ekumenizmu, Siedlce 1999, s. 76-77.

${ }^{21}$ Por. S. Nagy, dz. cyt., s. 251-275.

22 P. Jaskóła, Zagadnienia, s. 43.

${ }^{23}$ S. Pawłowski, Zasada hierarchii prawd wiary. Studium ekumeniczno-dogmatyczne na podstawie najnowszej myśli teologicznej (1984-2003), Lublin 2004, s. 43-56; por. W. Hryniewicz, Hermeneutyka $w$ dialogu, Opole 1998, s. 193-207; tenże, Hierarchia prawd, „Collectanea Theologica" 49 (1979), nr 3, s. 5-21. 
chu Ewangelii (DE 12) ${ }^{24}$. W ostatnim rozdziale, zatytułowanym: Kościoły i Wspólnoty kościelne odtaczone od Rzymskiej Stolicy apostolskiej, jest między innymi mowa o konieczności gruntownego i dobrego poznania innych wyznań, by móc dzięki temu prowadzić dialog ekumeniczny ${ }^{25}$.

Soborowy Dekret o ekumenizmie dał podstawę jakościowym przemianom w dążeniach ekumenicznych. Ważne w tym względzie wskazania, zalecenia i propozycje, zwłaszcza dla nauczania religii, zawarte zostały przez Sekretariat ds. Jedności Chrześcijan między innymi w takich dokumentach, jak: Dyrektorium ekumeniczne (cz. I - 196726; cz. II - 197027) oraz Dyrektorium $w$ sprawie realizacji zasad i norm dotyczacych ekumenizmu z 1993 r. (tzw. nowe Dyrektorium). Dyrektorium ekumeniczne w części zatytułowanej: Współudział z braćmi odłaczonymi w rzeczach duchowych zauważa, że dla odnowy jedności chrześcijan nie wystarczy praktykowanie wzajemnej miłości braterskiej w codziennym życiu, lecz potrzeba również współudziału w rzeczach duchowych, które są wspólne różnym wyznaniom chrześcijańskim. Należą do nich między innymi wspólnie urządzane modlitwy oraz współudział w czynnościach świętych (communicatio in sacris). Pożądane jest, według Dyrektorium, aby chrześcijanie przy różnych okazjach jednoczyli się na modlitwie i dzięki niej przyczyniali się dla dobra pokoju, sprawiedliwości społecznej, wzajemnej miłości wśród ludzi, godności rodziny itp. Modlitwa ta winna mieć również charakter dziękczynny. Natomiast głównym celem tych modlitw jest przywrócenie jedności między chrześcijanami (por. Dyr. I 21-24) ${ }^{28}$. Autorzy dokumentu zalecają także współudział w czynnościach świętych z braćmi wschodnimi od nas odłączonymi oraz współudział w czynnościach świętych z innymi braćmi odłączonymi. Wszystkie te wskazania podejmujące kwestię ekumenizmu duchowego i praktycznego zwracają jednoznacznie uwage na potrzebę kształtowania postawy modlitwy w nauczaniu religii. Będzie ona motywowała katechizowanych zarówno do indywidualnej modlitwy w intencji jedności Kościoła, do modlitwy we wspólnocie własnego Kościoła, jak i wyzwalała chęć uczestnictwa w różnych jej formach z przedstawicielami innych wyznań.

${ }^{24}$ A. Skowronek, Czym jest ekumenizm?, w: W. Hryniewicz, J. S. Gajek, S. J. Koza (red.), dz. cyt., s. 36-37.

${ }_{25}$ Por. A. A. Napiórkowski, dz. cyt., s. 84-85.

${ }^{26}$ Sekretariat ds. Jedności Chrześcijan, Dyrektorium do wykonania uchwat Soboru Watykańskiego II w sprawie ekumenizmu. Część I, w: S. C. Napiórkowski, Ut unum. Dokumenty Kościoła katolickiego na temat ekumenizmu, Lublin 1982, s. 112-130 (dalej: Dyr. I).

${ }^{27}$ Sekretariat ds. Jedności Chrześcijan, Dyrektorium do wykonywania uchwat Soboru Watykańskiego II w sprawie ekumenizmu. Część II: Ekumenizm w nauczaniu wyższym, w: S. C. Napiórkowski, dz. cyt., s. 131-148 (dalej: Dyr. II).

${ }^{28}$ Por. S. Nagy, dz. cyt., s. 241-248. 
Dla nauczania religii ważne są także kwestie opisane w drugiej części Dyrektorium, zatytułowanej: Ekumenizm w nauczaniu wyższym. Drugi rozdział tej części Dyrektorium podejmuje w pierwszej kolejności problematykę formacji duchowej i doktrynalnej, a więc kwestie istotne dla nauczania religii. W formacji duchowej zostaje podkreślona potrzeba nawrócenia serca oraz odnowa życia duchowego, która winna być głęboko zakorzeniona w życiu samego Kościoła, w jego liturgii i sakramentach oraz w modlitwie o jedność. Na gruncie formacji doktrynalnej Dyrektorium podkreśla, iż ekumenizm powinien wywierać wpływ na każdą naukę teologiczną ${ }^{29}$. W trzecim rozdziale pojawiają się szczegółowe przepisy dotyczące formacji ekumenicznej. Są one istotne dla nauczania religii. Autorzy dokumentu stwierdzaja, że dialog, jako nieodłączny element procesu wychowania, uzależniony jest od wielu czynników, między innymi od szczerej wierności dla własnej wiary, otwartego umysłu, gotowego do głębszego oparcia życia na własnej wierze, dzięki pełniejszemu poznaniu wyniesionemu z dialogu z drugimi oraz poszukiwania dróg i środków w celu nawiązania wzajemnych stosunków i przywrócenia jedności (Dyr. II, s. 140).

Analiza dwuczęściowego Dyrektorium ekumenicznego pozwala dostrzec wiele elementów, które pośrednio bądź bezpośrednio są istotne dla wychowania do postawy ekumenicznej w nauczaniu religii. Troska o ekumenizm duchowy, wypływająca z dokumentu, stanowi wytyczne dla kształtowania postawy modlitwy o jedność chrześcijan i to w znaczeniu zarówno indywidualnym, jak i zbiorowym w łączności z katolikami oraz członkami innych wspólnot chrześcijańskich. Koresponduje ona z założeniami programowymi nauczania religii w różnych typach szkół. Autorzy programu nauczania religii dostrzegają bowiem potrzebę zarówno formacji doktrynalnej, jak i kształtowania postaw związanych z realizacją ekumenizmu duchowego ${ }^{30}$. Świadczą o tym między innymi treści i cele programu nauczania religii, zwłaszcza w liceum i w szkole zawodowej ${ }^{31}$. Zaproponowane formy modlitwy oraz dialogu i kształtowania postawy otwartości na wyznawców innych wspólnot

29 Por. W. Hanc, Ekumeniczny wymiar catej teologii, w: W. Hryniewicz, J. S. Gajek, S. J. Koza (red.), dz. cyt., s. 581-586; T. Dola, Ekumeniczny sposób uprawiania teologii, w: P. Jaskóła (red.), Ekumenizm na progu trzeciego tysiaclecia, Opole 2000, s. 229-234.

${ }^{30}$ Komisja Wychowania Katolickiego Konferencji Episkopatu Polski, Program nauczania religii, Kraków 2001.

${ }^{31}$ Komisja Wychowania Katolickiego Konferencji Episkopatu Polski, Program nauczania religii dla liceum profilowanego , Świadek Chrystusa”, nr programu AZ-4-01/1, w: Komisja Wychowania Katolickiego Konferencji Episkopatu Polski, Program nauczania religii, s. 107-140; Komisja Wychowania Katolickiego Konferencji Episkopatu Polski, Program nauczania religii dla szkoty zawodowej ,ZZ Chrystusem ”, nr programu AZ-5-01/1, w: Komisja Wychowania Katolickiego Konferencji Episkopatu Polski, Program nauczania religii, s. 141-160. 
chrześcijańskich i religii z pewnością i dziś mogą okazać się skutecznymi środkami ekumenicznej formacji uczniów w nauczaniu katechetycznym ${ }^{32}$.

Duży wpływ na kształtowanie ekumenicznego wymiaru katechezy wywiera nowe Dyrektorium ekumeniczne Papieskiej Rady ds. Jedności Chrześcijan, zatwierdzone przez Jana Pawła II 25 marca 1993 r. ${ }^{33}$ Dyrektorium aż trzykrotnie odwołuje się bezpośrednio do katechezy, katechetów oraz do nauczania religii. Dokument, bazując na Dekrecie o ekumenizmie i poprzednim dwuczęściowym Dyrektorium ekumenicznym ${ }^{34}$, zaznacza, iż wszyscy ochrzczeni są powołani do angażowania się w poszukiwanie jedności, ponieważ „Komunia” w chrzcie jest przyporządkowana pełnej komunii eklezjalnej. Dlatego dokument zachęca, aby podjąć wysiłek ekumenizmu praktycznego tam, gdzie nie było jeszcze żadnej pracy w tym aspekcie (Dyr. III 22-23). Akcentuje także konieczność wychowania wiernych do postawy ekumenicznej. Według nowego Dyrektorium tego rodzaju działania mają na celu odnowę duchową uczniów, ich zaangażowanie na rzecz pokoju i sprawiedliwości, tak aby w efekcie rozwijali oni ekumeniczne aspekty własnych poczynań (Dyr. III 52) ${ }^{35}$. Jednak najbardziej znaczący dla ekumenicznego ukierunkowania nauczania religii jest fragment Dyrektorium poświęcony środkom formacji. Powołując się na Catechesi tradendae, dokument wyraźnie mówi o synchronizacji nauczania z życiem chrześcijańskim, do której katecheza winna prowadzić. Katecheza jednak powinna nie tylko nauczać, choć nauczanie zajmuje w katechetycznej posłudze istotne miejsce, lecz również i przede wszystkim winna ona przyczyniać się do kształtowania i formowania autentycznej postawy ekumenicznej. Po tej linii Dyrektorium postuluje zastosowanie sześciu dyrektyw:

1. Katecheza powinna jasno, z miłością oraz w sposób zwarty i syntetyczny podawać całą naukę Kościoła katolickiego, uwzględniając przy tym zasadę porządku i hierarchii prawd oraz zastosować taką terminologię i taką metodę przedstawiania doktryny, aby to nie stanowiło przeszkody w prowadzeniu dialogu.

2. Charakteryzując inne Kościoły i wspólnoty kościelne, należy przedstawiać ich naukę w sposób poprawny i lojalny, gdyż pośród elementów bu-

32 Tamże.

33 Papieska Rada ds. Jedności Chrześcijan, Dyrektorium w sprawie realizacji zasad i norm dotyczacych ekumenizmu z 25 marca 1993 r., w: S. C. Napiórkowski, K. Leśniewski, J. Leśniewska (red.), Ut unum. Dokumenty Kościoła katolickiego na temat ekumenizmu 1982-1998, Lublin 2000, s. 30-101 (dalej: Dyr. III).

34 Por. Z. Kijas, Ekumenizm, w: Jan Paweł II, Encyklopedia dialogu i ekumenizmu, Radom 2006, s. 191.

35 Por. J. B. de Pinho, Kościół katolicki $w$ dialogu teologicznym z innymi kościołami, „Communio” Polska 80 (1994), nr 2, s. 94-111. 
dujących Kościół wiele znamienitych może znajdować się poza widzialnym obszarem Kościoła katolickiego. Należy więc tak prezentować prawdy innych wyznań, by pomóc katolikom w pogłębianiu ich własnej wiary oraz we właściwym poznaniu i poszanowaniu innych braci chrześcijan, co w efekcie ma ułatwić wspólne poszukiwanie dróg jedności.

3. Katecheza będzie posiadała wymiar ekumeniczny, jeżeli wzbudzi i ożywi prawdziwe dążenie do jedności oraz spowoduje autentyczne wysiłki w kierunku wyeliminowania przeszkód na drodze ku jedności doskonałej, której pragnie sam Chrystus oraz przy pomocy wskazanych przez Niego środków. Na tym gruncie potrzebna jest pokora i żarliwość ducha w samooczyszczaniu się i przecieraniu dróg, a to z kolei nie może odbywać się za cenę eliminacji istniejących trudności ani tym bardziej przez ustępstwa w sferze doktrynalnej (Dyr. III 61c; por. Ct 32).

4. Ekumeniczny wymiar katechezy, mając na uwadze zachowanie tożsamości katolickiej, powinien w pełni uwzględnić formację katolików, którzy z szacunkiem odnoszą się do wiary innych. W takim klimacie powinien przebiegać proces ekumenicznego wychowywania i przygotowania dzieci, młodzieży i dorosłych (Dyr. III 61d; por. Ct 32).

5. W zastosowaniu ekumenicznego charakteru katechezy należy zwrócić szczególną uwagę na możliwości wynikające z odróżnienia prawd wiary od sposobów ich wyrażania. Dokonanie tego jest możliwe poprzez wspólny wysiłek, mający na celu poznanie i docenianie wartości obecnych w poszczególnych tradycjach teologicznych. Chodzi tutaj o takie wydobycie owoców dialogowych uzgodnień, które powinny prowadzić ku wzajemnej współpracy i pokojowemu współżyciu chrześcijan (Dyr. III 61e).

6. Kościoły lokalne, które będą opracowywały nowe katechizmy, muszą uwzględniać wskazania Catechesi tradendae (Dyr. III 61f) ${ }^{36}$.

Dyrektorium w dalszej części wskazuje na konkretne środowiska sprzyjające formacji ekumenicznej. Obok rodziny i parafii (Dyr. III 66a i b; III 67) ${ }^{37}$, wśród środowisk odpowiedzialnych za ekumeniczną formację wymieniona została szkoła, szczególnie związana ze środowiskiem nauczycielskim i katechetycznym. Tu pojawia się stwierdzenie, iż szkoła bez względu na rodzaj i poziom kształcenia „powinna nadawać wymiar ekumeniczny swemu nauczaniu religijnemu i zgodnie $\mathrm{z}$ właściwą sobie formą zmierzać do formacji serca i umysłu, do wartości ludzkich i religijnych, wychowu-

36 W. Hanc, Ekumeniczny wymiar katechezy, ,Studia Oecumenica” 4 (2004), s. 186-187; por. M. Czajkowski, Nowe Dyrektorium ekumeniczne, w: tenże (red.), W stużbie jedności. Sympozjum ekumeniczne w Akademii Teologii Katolickiej (18 marca 1994), Warszawa 1994, s. $220-221$.

37 G. Kusz, Ekumeniczna orientacja duszpasterstwa, w: W. Hryniewicz, J. S. Gajek, S. J. Koza (red.), dz. cyt., s. 790-791. 
jąc do dialogu, do pokoju i do relacji interpersonalnych" (Dyr. III 68; por. DWCH 6-9). Zadaniem szkoły na płaszczyźnie formacji ekumenicznej jest wychowanie w duchu miłości, szacunku i dialogu, w celu wyeliminowania uprzedzeń i zniekształceń zaciemniających właściwy obraz innych chrześcijan. To winno być szczególne zadanie szkół katolickich, gdzie młodzież ma wzrastać w wierze, w modlitwie oraz w nastawieniu do wprowadzania w życie chrześcijańskiej Ewangelii jedności (Dyr. III 68a). Ważna wydaje się być $\mathrm{w}$ tym zakresie współpraca $\mathrm{z}$ nauczycielami innych przedmiotów, np. historii czy sztuki, by i tam problemy ekumeniczne były prezentowane w duchu dialogu i jedności ${ }^{38}$. W końcowej części dokumentu pojawia się jeszcze jeden fragment poświecony wprost katechezie, który został opatrzony tytułem: Wspólpraca ekumeniczna w dziedzinie katechezy. Zawiera on następującą sugestię:

W ramach uzupełnienia zwykłej katechezy, jaką ze wszech miar katolicy powinni otrzymać, Kościół katolicki uznaje, że w sytuacjach pluralizmu religijnego współpraca w dziedzinie katechezy może ubogacić jego życie oraz życie innych Kościołów i wspólnot eklezjalnych, jak też umocnić jego zdolność do dawania, w miarę aktualnych możliwości, pośród świata, wspólnego świadectwa prawdzie Ewangelii (Dyr. III 188).

Według Dyrektorium, owa współpraca powinna być oparta na wspólnocie życia i na darach duchowych, popierających jedność i nadających odpowiednią rangę świadectwu Ewangelii, które winno cechować wszystkich chrześcijan. Współpraca może skutecznie przyczynić się do pokonania przeszkód na drodze jedności oraz do wspólnego świadectwa. W tych krajach, gdzie forma nauczania chrześcijańskiego wspólna katolikom i innym chrześcijanom jest narzucana przez państwo, posiada ona autentyczny walor ekumeniczny tylko wówczas, kiedy nauka ta przedstawia zgodnie z prawdą elementy nauki chrześcijańskiej. $\mathrm{W}$ takich sytuacjach należy jednak równocześnie zadbać o katechezę specyficznie katolicką (Dyr. III 189). W sytuacji zaś, gdy nauka religii odbywa się w szkołach przy współudziale członków religii niechrześcijańskich, trzeba włożyć wysiłek w to, aby uwypuklić jedność wiary, jaka istnieje między chrześcijanami na gruncie podstawowych zagadnień, jak również wyjaśnić istniejące różnice i ukazać kroki podejmowane dla ich przezwyciężenia (Dyr. III 189) ${ }^{39}$. Po linii tej myśli autorzy programu nauczania religii w polskiej szkole „kreślą” dyrektywy związane

\footnotetext{
38 W. Hanc, Ekumeniczny wymiar katechezy, s. 189-190.

39 Tamże, s. 55.
} 
z kształtowaniem postaw religijnie i wyznaniowo otwartych, a więc istotnych dla rozwoju współczesnego ruchu ekumenicznego ${ }^{40}$.

W świetle powyższych analiz dokumentów ekumenicznych Kościoła katolickiego pod kątem obecności w nich akcentów i interpolacji związanych z wychowaniem do postawy ekumenizmu można stwierdzić, że nauczanie religii jawi się jako nieodzowne środowisko i narzędzie w kształtowaniu właściwych postaw ekumenicznych. Dlatego też analizowane dokumenty w wielu miejscach podają pośrednio i bezpośrednio dyrektywy dla katechetycznej posługi słowa Bożego w Kościele i w szkole, dzięki którym będzie miała ona wymiar ekumeniczny. Ruch ekumeniczny współcześnie jawi się jako istotne zadanie Kościoła katolickiego i jeden ze znaków czasu (por. DE 4; UUS 8$)^{41}$, za którego realizację są odpowiedzialni wszyscy duszpasterze i katecheci, a nie tylko wybrani.

\section{Realizacja wychowania do postawy ekumenizmu w nauczaniu religii}

W praktyce wychowanie do postawy ekumenizmu, jak trafnie, a zarazem zgodnie $\mathrm{z}$ wytycznymi opisanymi w wyżej analizowanych dokumentach Kościoła, zaznacza C. Rogowski, wynika wprost z soborowej odnowy rozumianej ,jako proces uczenia się wspólnot chrześcijańskich, aż wspólnoty w swym ekumenicznym braterstwie zbliżą się do siebie i nawzajem przenikną, co w odniesieniu do pokoju, sprawiedliwości i ochrony środowiska oznacza w praktyce współpracę" ${ }^{\text {"2 }}$. Odpowiednim miejscem do formacji takiej postawy wydaje się nauczanie religii, o czym są także przekonani autorzy obowiązującego od 2001 roku programu nauczania religii w szkole podstawowej, gimnazjum i w szkołach ponadgimnazjalnych. Zwracają oni uwagę na zadania, które służą rozwijaniu postawy autentycznej otwartości na innych wyznawców i umiejętności prowadzenia dialogu nastawionego

40 Por. J. Urban, Dialog międzyreligijny w relacji do dialogu ekumenicznego, w: P. Jaskóła (red.), Ekumenizm, s. 253-258; tenże, Ekumenizm a ewangelizacja niechrześcijan, w: R. Porada (red.), Chrystus świattem ekumenii, Opole 2006, s. 93-101; M. Balwierz, Katolickie podstawy dialogu z religiami niechrześcijańskimi, w: W. Hryniewicz, J. S. Gajek, S. J. Koza (red.), dz. cyt., s. 676-701.

${ }^{41}$ Zob. J. Krasiński, Ekumeniczna encyklika Jana Pawła II pośród znaków czasu, „Więź” 1/447 (1996), s. 142-152.

${ }^{42}$ C. Rogowski, Koncepcje katechetyczne po Soborze Watykańskim II, Lublin 1997, s. 130 . 
na dążenie do jedności w różnorodności ${ }^{43}$. Według wytycznych zapisanych w programie nauczania religii owo rozwijanie w dzieciach i młodzieży postawy ekumenicznej sprowadza się do umacniania pogłębionej więzi z własnym Kościołem i budzenia poczucia odpowiedzialności za dzieło jedności całego chrześcijaństwa, z czym łączy się nierozdzielnie pragnienie jedności z braćmi innych wyznań ${ }^{44}$. Jednocześnie autorzy programu dostrzegają potrzebę kształtowania w uczniach zdolności do dialogu międzyreligijnego, nacechowanego poszanowaniem inności braci chrześcijan i niechrześcijan, tolerancja, zaangażowaniem, szacunkiem dla innych, zrozumieniem i otwartością na wartości tkwiące $\mathrm{w}$ innych religiach, a zarazem wiernością prawdzie $^{45}$. Z tym wiążą także potrzebę wzbudzania i podtrzymywania wśród katechizowanych pragnienia jedności oraz wdrażanie ich do nawiązywania i podtrzymywania kontaktów z niekatolikami, tak by szanując ich odrębność religijną, jednocześnie zachowywali własną tożsamość katolicką (Ct 32) ${ }^{46}$. Można zatem stwierdzić, że autorzy programu nauczania religii, planując wychowanie uczniów do postawy ekumenizmu czynią to zgodnie z założeniami opisanymi w dokumentach Kościoła. Za takim wnioskiem przemawiają przede wszystkim szczegółowe zapisy w programie Ś wiadek Chrystusa ${ }^{47}$ i Z Chrystusem $^{48}$, bowiem we wcześniejszych etapach edukacji religijnej kwestie ekumeniczne są potraktowane marginalnie i jedynie w kontekście nauczania doktryny katolickiej czy też rozwijania szeroko rozumianej postawy otwartości i dialogu. Na tej podstawie można rzec, że autorzy programu za odpowiedni czas do planowanego i celowego wychowania uczniów do postawy ekumenizmu uznają szkołę ponadgimnazjlaną. Zatem program Świadek Chrystusa kwestie istotne dla wyżej wymienionego celu katechezy ekumenicznej wpisuje w kontekst tematyczny korelacji z historią i geografią. Nawiązując do tematyki Kościoła katolickiego i chrześcijaństwa w Europie, proponuje się uświadomienie młodzieży wartości pojednania i przebaczenia

${ }^{43}$ Komisja Wychowania Katolickiego Konferencji Episkopatu Polski, Program nauczania religii, s. 43-160.

${ }^{4}$ Tamże.

${ }^{45}$ Więcej na ten temat piszę w: Ekumeniczny wymiar posoborowej katechezy w Polsce, Opole 2007.

${ }^{46}$ Kwestiom tym wiele uwagi poświęca między innymi E. Cholewka, Katecheza ekumeniczna, w: P. Jaskóła (red.), Ekumenizm, s. 272-273.

${ }^{47}$ Komisja Wychowania Katolickiego Konferencji Episkopatu Polski, Program nauczania religii dla liceum profilowanego ,Świadek Chrystusa”, nr programu AZ-4-01/1, s. 107-140.

${ }^{48}$ Komisja Wychowania Katolickiego Konferencji Episkopatu Polski, Program nauczania religii dla szkoły zawodowej ,,Z Chrystusem”, nr programu AZ-5-01/1, s. 141-160. 
win związanych z rozłamem w Kościele ${ }^{49}$ oraz ukazanie tradycji tolerancji w Polsce ${ }^{50}$. Takie zamierzenia służą zmianie mentalności młodzieży wobec wyznawców innych religii, a przez to wpisują się w proces kształtowania postawy otwartej na ekumenizm. Jednocześnie wśród zadań nauczyciela religii wymienia się tu przygotowanie młodzieży do dialogu z wyznawcami różnych religii ${ }^{51}$. Ma temu służyć między innymi korelacja $\mathrm{z}$ historia, gdzie jako istotne dla formowania postaw ekumenicznych wydają się stwierdzenia dotyczące tradycji tolerancji religijnej w Polsce ${ }^{52}$. W ramach korelacji ze ścieżką edukacyjną ,uczestnictwo w kulturze” zakłada się ukazanie istoty dialogu chrześcijańsko-żydowskiego, co wprost wskazuje na powiązanie tego zamierzenia z kształtowaniem postawy otwartej na ekumenizm ${ }^{53}$. Nie można bowiem zrozumieć tego dialogu bez odniesienia go do szeroko ujmowanego ekumenizmu, w którym ujawnia się szacunek dla Żydów i postawa otwartości ${ }^{54}$. Dzięki wszystkim tym działaniom powiązanym z wcześniej opisanymi treściami dotyczącymi poznania innych wyznań i religii zakłada się, że po zakończeniu katechizacji w II klasie uczeń liceum będzie potrafił „przyjmować postawę dialogu wobec innych religii, unikając niebezpieczeństwa indyferentyzmu" "55. Można więc stwierdzić, że we wszystkich wymienionych zakresach tematycznych, dotyczących wyznań i religii, w sposób naturalny obecne są zamierzenia związane z kształtowaniem otwartości na ruch ekumeniczny. Dalszą formację ekumeniczną wyznaczają propozycje zapisane w programie dla III klasy liceum, gdzie w kontekście tematyki życia małżeńsko-rodzinnego akcentuje się kwestie związane z dialogiem oraz tolerancją $a^{56}$. Pierwsza z tych umiejętności, rozpatrywana w kontekście ekumenicznego ukierunkowania katechezy, służy eliminowaniu uprzedzeń i pozwala na uzgodnienie stanowisk, poglądów, opinii dotyczących kwestii istotnych dla ruchu ekumenicznego ${ }^{57}$. $Z$ kolei postawa tolerancji znajduje wyraz w szacunku dla poglądów i przekonań osób inaczej wierzących ${ }^{58}$. Jest więc istotna w kształtowaniu wśród młodzieży otwartości na ruch ekumeniczny.

49 Komisja Wychowania Katolickiego Konferencji Episkopatu Polski, Program nauczania religii dla liceum profilowanego ,, Świadek Chrystusa”, nr programu AZ-4-01/1, s. 112.

50 Tamże, s. 113.

51 Tamże, s. 120.

52 Tamże.

53 Tamże, s. 122.

54 Tamże, s. 125.

55 Tamże, s. 129.

56 Tamże, s. 133, 136.

57 W. Hanc, Ekumeniczny wymiar katechezy, s. 200.

58 A. Dylus, D. Olszewski, Tolerancja, w: A. Zuberbier (red.), Stownik teologiczny, Katowice $1998^{2}$, s. 593. 
Wzmocnieniu wszystkich wyżej wymienionych działań służą także zalecane przez autorów programu metody oparte na dialogu i dyskusji ${ }^{59}$.

W wyżej opisanym kontekście merytorycznym i metodycznym należy też postrzegać działania formacyjne zakładane w programie $Z$ Chrystusem. Najpierw zmierza się do rozwijania wśród katechizowanej młodzieży umiejętności znalezienia się $\mathrm{w}$ sytuacji dialogu międzyreligijnego ${ }^{60}$, a więc takiej, która wymaga obok wymiany myśli także wymiany darów pomiędzy poszczególnymi jednostkami lub grupami różnych Kościołów i wspólnot religijnych, co wprost odnosi się do postawy otwartej na ekumenizm ${ }^{61}$. Działania te wymagają wyraźnego powiązania z treściami związanymi z wyznaniami chrześcijańskimi i innymi religiami, gdyż bez tego nie można mówić o właściwie kształtowanej postawie. Zgodnie z zamierzeniami autorów programu, zostaja one dopełnione o inne cele związane z kształtowaniem postawy otwartej na ekumenizm, na przykład o budzenie postawy dzielenia się miłością chrześcijańską ${ }^{62}$. Ich realizacji służą między innymi proponowane w programie metody dyskusyjne, zwłaszcza panelu i trybunału ${ }^{63}$. W konsekwencji wszystko to ma prowadzić do uformowania u katechizowanych uczniów postawy dialogu wobec innych religii. Służą temu pewne wskazania dotyczące ukazywania młodzieży zasad pracy w grupach i rozwijania związanych z tym umiejętności, na przykład poprzez zastosowanie metod opartych na dialogu ${ }^{64}$. Tym samym wpisują się one w ekumeniczne ukierunkowanie katechezy, gdyż rozwijają umiejętności niezbędne w dialogu międzyreligijnym. Tak więc w każdym z wyżej analizowanych programów nauczania religii, jakie obowiązują od 2001 roku, można dostrzec zróżnicowane założenia związane z kształtowaniem postawy otwartej na ekumenizm. Zwykle koncentrują się one wokół treści, które określają przedmiot tej postawy, a więc wokół wyznań chrześcijańskich i religii niechrześcijańskich, jak też celów ukierunkowanych na rozwijanie umiejętności dialogu międzyreligijnego oraz formowania postawy tolerancji i szacunku wobec osób inaczej wierzących.

59 Komisja Wychowania Katolickiego Konferencji Episkopatu Polski, Program nauczania religii dla liceum profilowanego „, Świadek Chrystusa”, nr programu AZ-4-01/1, s. 117, 128.

${ }^{60}$ Komisja Wychowania Katolickiego Konferencji Episkopatu Polski, Program nauczania religii dla szkoty zawodowej ,ZZ Chrystusem”, nr programu AZ-5-01/1, s. 144.

${ }^{61}$ Pisze o tym między innymi W. Hanc, Ekumeniczny wymiar katechezy, s. 201.

${ }^{62}$ Komisja Wychowania Katolickiego Konferencji Episkopatu Polski, Program nauczania religii dla szkoty zawodowej ,Z Chrystusem”, nr programu AZ-5-01/1, s. 148.

63 Tamże, s. 150.

${ }^{64}$ Tamże, s. 156, 158. 


\section{Podsumowanie}

Analiza dokumentów Kościoła i obowiązujących programów nauczania religii pokazuje, iż problematyka wychowania do postawy ekumenizmu w nauczaniu religii znajduje należne miejsce. Autorzy poświęcają wiele uwagi kwestiom związanym z poszczególnymi elementami tej postawy, a więc z poznaniem doktryny własnego Kościoła, z otwartością na wyznawców innych religii i ze zdolnością do dialogu międzyreligijnego. Za odpowiedni czas w wychowaniu do postawy ekumenizmu uznają głównie szkołę ponadgimnazjalną. Powstaje jednak pytanie, jakie przełożenie ma to na praktykę szkolną i dlaczego we wcześniejszych etapach edukacji religijnej ta problematyka zostaje marginalnie potraktowana? Ważne wydają się też odpowiedzi na pytania, ile czasu i w jaki sposób poświęca się w nauczaniu religii innym wyznaniom, szczególnie w sytuacji, kiedy w szkole są uczniowie innych wyznań chrześcijańskich? Niemniej znacząca jest tu postawa samego katechety wobec ekumenizmu oraz wyznawców innych wspólnot i religii. Jeśli potrafi on obiektywnie, życzliwie, odważnie, z wyraźnym wyakcentowaniem tego, co łączy, a nie, co dzieli, przedstawiać główne prawdy wiary na różnych poziomach nauczania, zestawiając je z nauką innych chrześcijan, wtedy można mówić o autentycznym zaangażowaniu w ruch ekumeniczny. Nie może przy tym zabraknąć ukazywania ewidentnych owoców dialogu. Aby w pełni odpowiedzieć na pojawiające się pytania i wynikające $\mathrm{z}$ nich implikacje dla praktyki należałoby w przyszłości nie tylko dokonać szczegółowej analizy poszczególnych serii podręczników do nauczania religii, ale także zrealizować badania empiryczne.

Istnieje zatem potrzeba, aby podejmować nieustanną, odwołującą się działan katechetycznych w szkole, refleksję nad jakością wychowania do postawy ekumenicznej w nauczaniu religii. Trzeba przy tym pamiętać, że „rzeczywisty ekumenizm nie istnieje bez wewnętrznej przemiany. Wszak z nowości ducha, z zaparcia się samego siebie i ze swobodnego wylania miłości pochodzą i dojrzewają pragnienia jedności. Dlatego u Ducha Świętego musimy wypraszać łaskę szczerego umartwienia, pokory i cichości w posłudze, a także wspaniałomyślności ducha wobec drugich" (DE 7). 


\section{Education to ecumenical attitude in teaching catechesis - catholic experiences (Summary)}

Education is a process that is directly connected with forming different attitudes in children and teenagers. It involves various aspects of human's development and different areas of human activity. It is oriented to comprehensive development of students. One of them is realized during catechesis which is educating children and teenagers to ecumenical attitude. The article first explains the basic concept of "ecumenical attitude". Next, it describes the assumptions of education in the ecumenical spirit according to the documents of the catholic church. The article also underlines the suggestions, resulting from these assumptions, for the theory and practice in teaching religion. Finally, it accounts for the need to deeper theoretical reflection and renewal of ecumenically oriented religion teaching. 
